\title{
Contemporary Gay and Lesbian Fiction in English
}

\author{
Hugh Stevens \\ Chapter for The Cambridge History of Gay and Lesbian Literature
}

\section{The emergence of gay and lesbian fiction as a genre}

Despite commonly held preconceptions about fiction before Stonewall, a number of British and American novels represented gay and lesbian lives during World War Two and in the postwar period. Queer characters became increasingly visible in literary fiction, taking starring roles in novels by a range of writers, including Carson McCullers, Truman Capote, Angus Wilson, James Baldwin, Christopher Isherwood, Jane Rule and Maureen Duffy. ${ }^{1}$ Although academic literary criticism largely ignored contemporary fictional representations of homosexuality, many queer novels were reviewed in leading newspapers, receiving a range of positive and negative responses. And queerthemed pulp fiction sold in enormous numbers, revealing a huge popular demand for fictional representations of gay and lesbian lives. Paperback originals were more free to represent taboo topics than cinema, radio, and reputable hardcover books, and "more than two thousand lesbianthemed mass-market books were published between 1945 and 1970" (Stryker 61), as well as pulp titles dealing with male homosexuality, bisexuality, transvestism and transsexualism. ${ }^{2}$ Scholarly attention to this period has enabled a more nuanced account of gay and lesbian literature since 1970. Michael Bronski's refutation of the "myth that there were few (or no) books about homosexuality before Stonewall," and the "contradictory, but equally strong, myth that all of the pre-Stonewall novels had tragic endings" (11) enables us to see continuities in the development of queer writing across the postwar decades.

From the 1950s, a range of fiction and non-fiction books on queer subjects were available as cheap paperbacks. Paperback originals included sensationalist and lurid tragic tales of doomed homosexual passions, as well as more nuanced representations of lesbian life which showed the difficulties of being a dyke in the big city, usually New York, such as the best-selling "Beebo Brinker chronicles" by Ann Aldrich. There were also reprints of classics (marketed as lurid tragic tales in ways which belied their complexity) like Émile Zola's Nana (1880) and Radclyffe Hall's The Well of Loneliness (1928), and of a range of literary novels, originally published in hardback, which gave more positive or political representations of queer existence, such as Vidal's The City and the Pillar (1948; discussed below) and Patricia Highsmith's Carol (first published pseudonymously in 1952 as The Price of Salt, by Claire Morgan), a romantic novel which shows a lesbian couple resolving to live together despite difficult circumstances.

After 1970, gay and lesbian fiction has been constituted, somewhat problematically, as a genre (or often as two distinct genres). The identification of genre in relation to the representation of sexuality - as opposed, say, to other thematic concerns such as nationality, race, and class, or formal divisions such as realism, modernism and postmodernism - is restrictive in some ways, enabling in others. A gay novel can of course also be other kinds of novel - an Irish novel, a historical novel, an African-American novel, for instance. The recognition of the genre of queer fiction allows critics and readers to ask a range of questions concerning the representation of queer life, and makes queer lives more visible in our culture. Nevertheless, some novelists who are gay or lesbian have rejected the label of gay and lesbian writing as limiting; others have written novels consciously constructed and marketed as politicized queer fiction, often published by specialist presses. Many 
writers have given qualified endorsements the idea of gay and lesbian fiction, cautioning against excessive reliance on it.

When Alan Hollinghurst's The Line of Beauty won Britain's 2004 Booker Prize, debates about "gay fiction" circulated in the British press in ways that echoed decades of ambivalence toward the category on the part of queer readers, writers and critics. In a Guardian interview, Hollinghurst was asked how he felt about headlines such as the Daily Express's "Booker Won by Gay Sex" and the Sun's "Gay Book Wins." His reply shrewdly foregrounded the limitations and possibilities of thinking about gay writing as a genre: "I only chafe at the 'gay writer' tag if it's thought to be what is most or only interesting about what I'm writing ... the books ... are actually about all sorts of other things as well - history, class, culture ...It's not just, as you would think if you read the headlines in the newspapers, about gay sex" (qtd. in Moss).

One might enlarge on Hollinghurst's position. It isn't surprising that gay and lesbian fiction has often been concerned with sexual questions, but queer novels have never been "just" about sex and sexuality. Their representation of sexuality has been varied and complex, and they cannot be seen as constructing a uniform and consensual position on queer sexual behavior and politics. Many fiction-writers (including Pat Califia, Dennis Cooper, Samuel Delany and Jane DeLynn) show characters enjoying transgressive sex in urban sub-cultural spaces, whereas others (Isabel Miller, David Leavitt) show characters with little interest in urban queer scenes. Gay and lesbian fiction since 1970 has concerned itself not only with gay sex, history, class, culture, the very question of queer identity itself (to what extent does homosexuality constitute an identity?), but also with gay relationships, relationships of queer protagonists with their families, the nature of life in gay and lesbian subcultures, living with HIV/AIDS. These themes have been explored in relation to a range of explicitly political questions, such as the treatment of queers by the culture at large, as well as debates within queer culture about queer identity, lifestyle, race and ethnicity, and the identification of homosexuality as necessarily dissident, virtually normal, or somewhere in between these pole positions. The development of contemporary queer fiction has paralleled the development of queer cultures, which have enabled the recognition of what Matt, the butch lesbian character central to one of the most important and most accomplished of lesbian novels written before Stonewall, Maureen Duffy's The Microcosm (1966), presciently identified as "dozens of ways of being queer" (273). Queer fiction since Stonewall, in its heterogeneity, has reflected the heterogeneity of queer identities, culture and politics.

If writers were canonized according to what we might call, after Joni Mitchell, the "starmaker machinery" behind the successful literary novel, a machinery that depends on four kinds of celestial identification - sales figures (the reward of the marketplace), book reviews (the approval of the press), literary prizes (the arbitrary seals of approval awarded by distinguished jurors), and academic literary criticism (institutional beatification) - then our canon of gay and lesbian Englishlanguage fiction might include Edmund White, Alan Hollinghurst, Jeanette Winterson, Alice Walker, Colm Tóibín, Sarah Waters, and ... who else? One can think of many writers who might get one star but how many earn two or three? There is no agreed corpus of contemporary queer fiction that can be recognized as the best and most worthy, and readers who are keen to explore contemporary queer fiction will discover that there are as many ways of writing LGBT-themed fiction as there are ways of being queer. The narrator of Edmund White's The Farewell Symphony (1997) recalls that many of the many men he had sex with in the late sixties would also tell him "their stories, as though the main pressure behind cruising were narrative rather than sexual ... The silence imposed on homosexuals had finally been broken, and we were all talking at once" (47). Gay and lesbian fiction 
might be thought of as a large room, or a library, full of such stories, in which case the literary historian's attempt to narrate their history will only be another story, subject to revision and objections. Although mainstream gay and radical queer politics and theory since 1970 have often brought lesbian and gay male concerns together, lesbian and gay male fiction have followed different trajectories, in some ways crossing, in others separate.

\section{Post-Stonewall lesbian fiction}

Gay liberation and lesbian feminism enabled the development of a new and radical lesbian fiction, which was not content with telling stories of lesbians accommodating to prejudices and the pressure to remain closeted to society at large, unable to live openly outside an enclosed community. In The Microcosm (1966) a large cast of lesbian narrators tells us their stories, all of which show the pressures of living in the "microcosm," namely "the gay world as a universe in little" (286-7). Duffy's novel begins in despair - its opening scene describes the burial of the butch Carol, or Carl, who has gassed herself - and ends in tentative hope. Many of the lesbians in the House of Shades (based on London's most important lesbian club in this period, the Gateway Club, which ran from 1930 to 1985) are butches or femmes, and at the end of the novel Matt (who refers to himself as "he") is wanting to break out of this sub-cultural world. He rejects the idea that he should continue to live in "the gay world as a universe ... a microcosm if you like," and decides instead that queers should "learn to live in the world," which "should live with us and make use of us, not as scapegoats ... but as who we are" (286-7).

Matt's decision might be seen as typical of a pre-Stonewall political formation - the politics of the homophile movement - in which the task of the lesbian or gay man is to adapt to the world, while working to make the world a more tolerant place. ${ }^{3}$ Lesbian feminism and gay liberation, however, rejected liberal agitation in favour of a more radical, transformational politics expressed through revolutionary activism. Lesbian feminists of the early seventies aimed for nothing less than a wholesale re-making of the world, or the creation of a "lesbian nation" apart from the world, a world of "women-identified women."

The emergence of a new radical lesbian fiction, which did not conform to the demands of the mass fiction market, was enabled by the formation of feminist and women's presses in the 1970s and 1980s. ${ }^{5}$ New independent presses, including Daughters, Inc., Naiad Press, and Seal Press in the United States, and The Women's Press, Onlywomen Press and Virago in the United Kingdom, began published lesbian writing in a range of genres, including fiction, poetry, historical and political and writing. ${ }^{6}$ The highly politicized fiction that emerged from these presses worked in tandem with a range of non-fiction titles appearing in the early 1970s that advanced a radical theory and politics, including Del Martin and Phyllis Lyon's Lesbian/Woman (1972), Sydney Abbott and Barbara Love's Sappho Was a Right-on Woman (1972) and Karla Jay and Allen Young's Out of the Closets: Voices of Gay Liberation (1972). These titles helped form a political consciousness for numerous readers, including remarkable genre-crossing and gender-crossing cartoonist Alison Bechdel, born in 1960. In her graphic memoir Fun Home: A Family Tragicomic, Bechdel shows herself devouring these political works at college alongside a range of queer fiction, in an extraordinary reading odyssey which began when she was nineteen. In one of her illustrated memories, she is reading seventy-seven-year old Elsa's account of her lesbian identity in Nancy and Casey Adair's Word Is Out: Stories of Some of our Lives (1978), a book of interviews of lesbians and gay men who had, Bechdel notes, "completely cast aside their own qualms" about their sexuality (74). Reading titles like these, she recalls, helped her 
realize that she was a lesbian "in a manner consistent with my bookish upbringing"; this revelation was "not of the flesh, but of the mind" (74). But of course her reading was extracurricular: in the early 1980s, lesbian and gay literature was not part of the university syllabus. In retrospect she wishes she had called it an "independent reading," noting that "'Contemporary and Historical Perspectives on Homosexuality" would have had quite a legitimate ring" (205).

Lesbian fiction of the 1970s and 1980s is wide-ranging and defies easy classification. The independent presses published serious "literary fiction" alongside innovative genre fiction. Lesbianfeminist utopian and science-fiction novels by writers such as Joanna Russ (The Female Man, 1975) and Sally Gearhart (The Wanderground, 1978) began to explore the possibility of separatist female communities. ${ }^{7}$ Since the 1980 s, many writers have written entertaining and political lesbian crime fiction: these include Barbara Wilson (Murder in the Collective, 1984), Mary Wings (She Came Too Late, 1986, and other novels featuring detective Emma Victor, who investigates crime in lesbian and gay communities in Boston and San Francisco), and Katherine V. Forrest (Amateur City, 1984, and other Kate Delafield mysteries). ${ }^{8}$ The best-selling lesbian novel of the decade, Rita Mae Brown's Rubyfruit Jungle - first published by Daughters, Inc in 1973, and subsequently released as a massmarket paperback by Bantam in 1977 - is often seen as definitive of fiction of this period. Its narrative of the coming-of-age of a feisty lesbian protagonist who moves from provincial origins when the novel opens Molly Bolt is a seven-year-old girl living in "Coffee Hollow, a rural dot outside of York, Pennsylvania" (3) - to the metropolitan destiny of New York's queer community, is certainly a prototypical "coming-out" story, but the realist Bildungsroman was only one of many kinds of lesbian novel published since $1970 .{ }^{9}$ Only a few of the novels from this period portray queer childhoods, and those that have adult lesbian protagonists often tell stories of lesbians who are already out when the novel begins.

In any case, the marketing of fiction as "lesbian fiction" freed the novelist from the requirement making the establishment of the protagonist's queerness an integral part of the narrative. Sister Gin, June Arnold's comic novel about a book review editor, Su, radicalizing herself at the age of fifty, is stylishly confident in its representation of lesbian relationships and desires. "Su was [Bettina's] queen of scarves," we are told at the beginning of this novel about a group of (mostly lesbian) genteel women living in Wilmington, North Carolina. Bettina and Su regularly have dinner as a couple with Luz, Bettina's mother, and their friends include seventy-seven-year-old Mamie Carter, lesbian grandmother and vigilante radical (Mamie's bridge-playing friends, under the name of the "Shirley Temple Emeritae," deal out appropriate punishments to Wilmington's rapists). Sister Gin does engage with the politics of "coming out": Su comes out to her mother, who responds by thinking that "that word" (lesbian) "isn't a nice word," that "people don't care what you think as long as you don't tell them about it" (82). And Su keeps her job at Wilmington's (ironically named) Commercial-Appeal by avoiding reviewing books with lesbian content. But coming out is only one concern in Arnold's stylish novel, alongside aging, menopause, sexual politics and race relations, and (as the title indicates) the temptation to drink too much gin.

The most challenging of 1970s lesbian novels, Bertha Harris's Lover (1976), assembles a fantastical cast of magical women, and sets them loose in a genre-bending and gender-bending performance incorporating opera, drama, Hollywood movies and saints' narratives. Lover suggests the modernism of Virginia Woolf (its playful collapsing of the boundaries between fact and fiction, history and invention, biography and novel are reminiscent of Orlando) and Djuna Barnes (it shares with Nightwood a fascination with the carnivalesque, the burlesque, and popular entertainment such as vaudeville and the circus)..$^{10}$ It shows as well a sharp and original appropriation of post- 
modern fiction. Its celebration of lesbian eroticism and love between women and its playful depictions of gender-crossing and drag work paradoxically to "de-naturalise" the very sign of lesbian. Its postmodernity, magic realism, and self-reflexiveness show Harris conversant with avant-garde fiction of the sixties and seventies - her narrative innnovations bring to mind a range of novelists writing after World War Two, including Donald Barthelme, Angela Carter and Thomas Pynchon. What makes Lover unique is the fun with which it portrays one of its characters, Veronica, as the lesbian novelist within the novel creating the lesbian novel that it is our pleasure to read. Lover opens with a synopsis of Richard Strauss's Der Rosenkavalier, so "the first thing we see" is the Marschallin in bed with her young man Octavian, "played by a very young woman" (3). It then segues to Saint Lucy, who has gouged out her own eyes, being visited by Saint Agatha (whose breasts, as we learn a few pages later, were cut off when she spurned the advances of Quintian). Agatha tells Lucy (in one of many erotically charged encounters between female saints in the novel): "Thou art light" (5). The next fluid move is to the births of Samaria, Daisy and Flynn, three generations of lovers, and then Veronica, the novel's novelist and forger of Old Masters, whose lover gives her "an old silver cigarette case, with the initials BH engraved in one corner of the lid" (6). The novel collages together fragments in a manner that is at first bewildering as the reader negotiates switches from third-person narration to a range of first-person segments with different narrators, sometimes identifiable as one of the novel's characters, and sometimes anonymous. One of the narrators, the novel teases, might be Bertha Harris herself, whose identity often seems indistinguishable from that of Veronica, just as "Veronica's veil took the face [of Christ] on itself and afterwards no one could tell which was the real face and which was the face on the veil" (58). But postmodern playfulness do not prevent the novel giving a seductive account of New York lesbian life in the early seventies. In her introduction to the novel Harris describes it as "the pleasure dome" she imagined for the "intellectually gifted, visionary, creative and sexually subversive women" she had met in the "women's liberation movement" (xx-xxi), and Lover inventively merges politics with pleasure, makes "the lesbian" visible while also acknowledging (in ways that anticipate 1990s queer theory) the provisional, fragmentary and performative nature of lesbian identity.

The close interface between fiction and politics has remained visible in some but not all lesbian fiction that has emerged since the 1980s. The most politically engaged lesbian novelist in this period is New Yorker Sarah Schulman, who after many years as a member of ACT UP (the AIDS Coalition To Unleash Power) became a founding member, in 1992, of activist organization Lesbian Avengers. ${ }^{11}$ Schulman depicts New York's gay and lesbian subculture - in particular the bars and clubs of the Lower East Side - and the political struggles of the 1980s and 1990s in a range of savvy, witty and irreverent postmodern novels, which often interact with and deconstruct other genres. Her first novel, The Sophie Horowitz Story (1984), parodies the detective novel, with its eponymous heroine, a journalist trying to unravel what has happened to radical lesbian feminists Germaine Covington and Laura Wolfe, who have vanished after robbing a bank. People in Trouble (1990) and Rat Bohemia (1995) portray the new queer radicalism of 1980s New Yorkers struggling with the ravages of the AIDS epidemic.

The best-known lesbian novelist to emerge in the 1980s, however, is Jeanette Winterson, whose fictions create romantic myths of lesbian desire which aren't explicitly tied to any communitarian politics. Her hugely popular first novel, Oranges Are Not the Only Fruit (1985), an autobiographical Bildungsroman, portrays a young girl - also called Jeanette - in a working-class Lancashire town realizing her lesbian identity in the most unpromising and hostile family environment. Jeanette's adoptive mother - an Elim Pentecostalist - is convinced that Jeanette, a 
talented child preacher, has ahead of her a promising career as a missionary, but these plans come up against an insurmountable obstacle when Jeanette falls in love with her friend Melanie. The church does not agree with Jeanette's view that "Melanie is a gift from the Lord, and it would be ungrateful not to appreciate her" (102). The novel is marvelously comic and upbeat, despite its painful depictions of the cruel treatment Jeanette receives at the hands of Pastor Spratt and the church elders. They condemn her as "impure" and "unnatural" and attempts to exorcise her of her lesbian demon (which returns "sevenfold").

The prose of Oranges, brimming with echoes of scripture, biblical cadences, and the prophetic utterances of Jeanette's mother, is highly original. The novel creatively interweaves realism based on vivid evocations of events and sharp specification of concrete detail with postmodern fables, many of them based on the Grail legend, paralleling Jeanette's ordeal with Perceval's quest for the "Holy Grail covered with white samite" (161). Winterson's subsequent novels abandon realism for her own original hybrid of postmodernism, magic realism, parody and fantasy, which makes problematic any straightforward understanding of her fiction as "lesbian." The Passion (1987) and Sexing the Cherry (1989), with their fantastical characters such as the bisexual, androgynous, cross-dressing Villanelle, and the monstrous giantess the Dog Woman, have been read by some critics as lesbian postmodern subversions of the normal and the natural, and criticized by others as evading material and political realities. ${ }^{12}$ Written on the Body (1993) has proved easier to interpret as a lesbian novel, despite the fact that its narrator is un-named and never (explicitly) reveals her gender. The love of the "I" of the novel for a married woman, Louise, is figured as a grand romantic passion. While the plot of the novel is (self-consciously) melodramatic, sentimental and implausible - "I" leaves Louise so that her husband, a leading cancer researcher, can give her the best treatment available - these "Operatic heroics and a tragic end" (187) move "I" to celebrate "the cells, tissues, systems and cavities" of Louise's deteriorating body in a series of erotic and devotional prose poems or arias. Here is "I" singing the praises of Louise's "cavities":

Let me penetrate you. I am the archaeologist of tombs. I would devote my life to marking your passageways, the entrances and exits of that impressive mausoleum, your body. How tight and secret are the funnels and wells of youth and health. A wriggling finger can hardly detect the start of an ante-chamber, much less push through to the wide aqueous halls that hide womb, gut and brain. (119)

Critics have compared the novel's textual erotics with Monique Wittig's The Lesbian Body (1973) and Roland Barthes's The Lover's Discourse (1977), as well as with other lesbian novels of rapturous love. "Engulfment is a moment of hypnosis," writes Barthes; here we see Winterson, like Barthes, endlessly sustaining "the discourse of the lover's absence" $(11,15)$.

\section{The erotic city of gay male fiction}

More than any other novel of the period between the end of World War Two and Stonewall, Vidal's The City and the Pillar (1948) anticipates the many gay novels of the late twentieth century which explore gay identity in relation to a gay subculture. The novel gave remarkably candid accounts of what it describes as the "abnormal underworld" of Hollywood, which is "closer to the surface than anywhere else in America," the "homosexual bars" of New Orleans, and the "well-organized homosexual world in New York," which drew "thousands" from "all over the country," where they 
"had nothing to lose by being free and reasonably open in their behaviour" $(67,82,152-3)$. Just as important, the novel's articulation of the importance of coming out of the closet anticipates the politics of the 1970s gay liberation movement. When the novel's hero, Jim Willard, travels from New York, where he enjoys "four or five" sexual encounters a week with men he meets in gay bars, back to his hometown in Virginia to visit friends and family, he finds himself "impatient of the masquerade" $(157,173)$. His desire to "come out and tell them what he was and defy them" $(173)$ echoes a striking argument made by his friend Paul Sullivan in a gay bar in New Orleans. Paul argues that homosexuals "must declare ourselves, become known; allow the world to discover this subterranean life of ours which connects kings and farm boys, artists and clerks" (84). ${ }^{13}$

This "subterranean life" surfaced in explicit detail in an explosion of gay fiction which began in the late 1970s. If heterosexuality was associated by gay liberation with the monogamous couple, this new gay fiction showed homosexual men enjoying sex with a range of different partners not only in bedrooms but also in cruising areas, bars, sex clubs and bathhouses. 1978, often described as a key year for gay fiction, saw the publication of Larry Kramer's Faggots, Andrew Holleran's Dancer from the Dance, and the first of Armistead Maupin's popular and entertaining Tales of the City novels, set in San Francisco. Kramer's novel, a comic satire often criticized for its sensationalism, formlessness and wooden writing, is a moralistic attack on gay promiscuity in New York, showing characters with names like Randy Dildough and Jack Humpstone frequenting such locales as the Toilet Bowl and the Everhard Baths. The novel's hero, Fred Lemish' rather implausibly hopes to find his perfect match in this heartless world. Dancer, by contrast, offers a rapturous celebration of the same urban ghetto: its men, "bound together by a common love of a certain kind of music, physical beauty and style," danced with "the ecstasy of saints receiving the stigmata" (38). The beautiful face of its hero, Anthony Malone, glows with "radiant exhilaration" when he dances, which makes others think that he "took speed, when he didn't. It was his joy that there were men who loved other men" (230).

Over the next two decades American gay male fiction transformed itself from a field of isolated figures to a crowded scene. ${ }^{14}$ The most comprehensive fictional account of postwar gay history sees gay lives through the lens of an individual, the unnamed protagonist and narrator of Edmund White's trilogy of autobiographical novels, which collectively portray American gay men as a group "oppressed in the fifties, freed in the sixties, exalted in the seventies and wiped out in the eighties" (Farewell Symphony 405). The fortunes of White's narrator - let's call him "Ed" for ease of reference - are closely related to the trials, tribulations, triumphs and sorrows of the group, even though he spends many years trying not to become a member of it. The boy of A Boy's Own Story (1982), growing up in the Midwest in the 1940s and 1950s, is "sunk into a cross-eyed, nose-picking turpitude of shame and self-loathing," is aware of himself as "a sissy" who would flunk any "quiz for masculinity," and is appalled at his own homosexuality because he "never doubted that homosexuality was a sickness" $(126,9,118)$. The Beautiful Room Is Empty (1988) takes Ed from the mid-fifties, remembered as a time when "[t]he three most heinous crimes known to man were Communism, heroin addiction and homosexuality," and ends with his ambivalent participation in the Stonewall riots, torn between an urge "to be responsible and disperse the crowd peacefully" - a feeling that it is only foolish to protest "[o]ur right to our 'pathetic malady"" - and a "wild exhilaration" that he sees as a "gleeful counterpart" to rage $(7,182)$. White's prose in this novel is often gorgeous, ornate, baroque with the "goldest filigree" (150) of a young girl's blond hair illuminated by the evening sun passing through it. But the stories he tells - such as that of his lover Lou, the heroin addict who has damaged his digestive tract by biting through a thermometer and 
swallowing "all the broken glass and the mercury too," so that when he shoots up he requires a "high colonic irrigation" - are appalling in their intensity, shot through with the same "self-hatred" that consumes Ed the undergraduate every time he looks for anonymous sexual encounters in the Student Union toilets (111-6, 59).

While White's autobiographical fiction explored his childhood and youth, much fiction of the 1980 s continued to describe contemporary gay life in urban centres. The exhilaration of Dancer, however, was to change utterly with the arrival of the AIDS epidemic. Toward the end of Nights of Aruba (1983), Andrew Holleran's second novel, Paul, the main character and narrator of the tale, mentions that "Celebrities of our sexual demimonde were dying of bizarre cancers" (232). The "cancer," Paul's friend Mr Friel infoms him, "has everyone so frightened not that they won't just sleep with anyone anymore"; Mr Friel is seeing a young man "interested in knowing a person before he sleeps with him. He told me so! He wants to put sex after intimacy, rather than the other way around" (233). It is notable that this early mention in fiction of AIDS (although Holleran does not yet have a name for it) already connects it with anxiety about sexual intimacy. Fictional celebrations of sexual pleasure, nonetheless, proliferated in the 1980s and 1990s, but this same fiction also registered what British author Adam Mars-Jones called "The Changes of Those Terrible Years" (227). These changes are sometimes only hinted at in 1980s fiction. William Beckwith, the protagonist of Alan Hollinghurst's wonderfully assured first novel, The Swimming-Pool Library (1988), recalls his erotic adventures in London in 1983; AIDS, nowhere mentioned in the novel, is only the "faint flicker of calamity, like flames around a photograph, something seen out of the corner of the eye" as he enjoys "the last summer of its kind there was ever to be ... my belle époque" (3). Will's erotic peregrinations bring him in contact with the elderly Charles Nantwich, and through his friendship with Charles he becomes increasingly aware of queer lives of the past. Historical and political awareness temporarily shatter his leisurely pleasure dome, but at the end of the novel he sees "a suntanned young lad in pale blue trunks that I rather liked the look of" (288).

In much gay fiction since the late 1980s, however, the terrible changes are faced directly. Many of the best novels about AIDS contrast life before and after the epidemic. In the third novel of White's trilogy, The Farewell Symphony, the beautiful room is crowded with men enjoying the erotic life of post-Stonewall America, though the novel ends with many of them departing, just as the musicians leave the stage in Haydn's playful symphony that gives the novel its title. The first ten chapters register the wondrous changes in New York's gay scene from 1968 to the end of the 1970s, a period in which Ed believed "that the couple would disappear and be replaced by new, polyvalent molecules of affection or Whitmanesque adhesiveness," in which gay men "wanted sexual friends, loving comrades, multiple husbands in a whole polyandry of desire. Exclusivity was a form of death worse, old hat" $(341,246)$. The reader familiar with gay culture and gay fiction will not be surprised that the last, eleventh chapter begins by recalling that "Somebody at my gym became ill" (364), but familiarity makes the ending of White's symphony no less sad or terrifying. The novel is an elegy not just for friends, sexual partners and lovers, but for a way of life.

Some fiction by novelists who were HIV-positive and died before the introduction of antiretroviral therapies captured the realities of living with AIDS with painful immediacy. ${ }^{15}$ British novelist Oscar Moore's A Matter of Life and Sex (1991) shows its protagonist Hugo continuing to look for sex "even in the jaws of the disease, even as the cities he played in were turning to funeral parlours" (145). That Moore was exploring his own life (he had been HIV-positive since he was twenty-three, and died at the age of thirty-six in 1996) is brilliantly hinted at in the pseudonym under which he first published the novel: Alec. F. Moran is an anagram of roman à clef. In 
Christopher Coe's Such Times, published in 1993, one year before he died, Timothy's descriptions of his present life - he is writing in the summer of 1992, has recently lost his lover Jasper, and his friend Dominic is seriously ill - are interspersed with memories of his first meeting Jasper eighteen years ago, in New York's Continental Baths, and of the intervening years. Autobiography merges movingly with fiction in David Feinberg's accounts of the adventures of his alter ego B.J. Rosenthal in EightySixed (1989) and Spontaneous Combustion (1991). Everyday life is recorded in sharp particularity, as if in a journal. Feinberg and Coe exploit the openness and fluidity of the novel form to write highly politicized yet entertaining biographical fiction, preoccupied with time and mortality. The first part of Eighty-Sixed, "1980: Ancient History," shows B. J. enjoying visits to the St. Mark's Baths, and evenings at bars and clubs such as the Flamingo, 12 West, the Stud, and the Spike. The second half of the novel, "1986: Learning How to Cry," moves subtly and chillingly from past-tense to presenttense narration. It opens with a prologue giving statistics of HIV-infection in January 1986: "At present there is no cure for AIDS," B. J. tells us, as he calculates the odds that he is infected. In this "age of anxiety," gay men are going to the gym "to keep out of trouble," and intimacy with others has been replaced time spent "home with the VCR, watching porno, 'Masterbates Theatre'" ( (201). Eighty-Sixed describes a world in which AIDS permeates everyday existence: obituaries proliferate in the gay press, telephone conversations are filled with tales of disease and dying, and the only weapon to ward off despair is mordant humour. In Spontaneous Combustion, B.J. tests positive, joins ACT UP, and hopes for "some sort of cure in the future" (80). An appendix to the novel imagines "hundreds of thousands of ecstatic fags and dykes" celebrating the cure for AIDS, but doesn't tell us if B. J. has survived to join them (223). B. J.'s creator died on November 2, 1994, aged thirty-seven.

\section{Fiction After Queer Radicalism}

"Saffron said she would buy the flowers herself. Anything to get away from Mummy and Meredith." The novel with a young straight but queer Goth protagonist, her piercings and tats disapproved of by her suburban Tory lesbian parents (married, of course), hasn't quite been written: the so-called "mainstreaming" of gay and lesbian identities has been conspicuous in its absence in recent gay and lesbian fiction. But in Michael Cunningham's Pulitzer Prize-winning novel The Hours (1998), Clarissa Vaughan regrets “the lovely little black dress she can't buy for her daughter because Julia is in thrall to a queer theorist and insists on T-shirts and combat boots" (21). This "almost scandalously privileged" lesbian mother struggles to get on with her daughter's friend Mary, who also wears butch boots and hates shopping as "such a waste of time" $(10,159)$. Although queer fiction isn't over-populated by same-sex couples with children, in many gay and lesbian novels written in the past few decades, by writers like Cunningham and David Leavitt, homosexuality and familial life are by no means antithetical.

In many recent gay and lesbian novels, the lines connecting queer identity and radical politics are occasionally redrawn, and at times are missing altogether. Queer identities are accommodated in a world more tolerant than that portrayed in radical fiction of the post-Stonewall period. Colm Tóibín's The Blackwater Lightship (1999), with its cast of three women, grandmother, mother and daughter Helen, and three men, Helen's brother Declan and his gay friends Larry and Paul, all trying to look after Declan, who is dying of AIDS, confronts familial and provincial Ireland with the confident and sad energies of the queer metropolis. The scene queens in Alan Hollinghurst's comic novel The Spell (1998), on the other hand, live in an almost hermetically sealed gay male world, although Robin once knew a woman named Jane who provided him with a son, 
young Danny, whose love of casual sex and drugs and clubs doesn't prevent him becoming amourously entangled with Alex, the ex of his father's younger lover Justin. Justin, an unemployed actor who doesn't lack financial resources, likes shopping. One hot summer afternoon he takes a taxi from Harvey Nichols to Issey Miyake, where he spends more than $£ 3,000$ on a suit and shirt, then returns to the Musgrove Hotel where he pays "large vague sums of money" to be urinated on by Carlo the "Italian hunk," a rent-boy whose size is twenty-five, "in centimetri, of course" (194). Other things happen as well in this novel, which is ironic, perhaps, in its portrayal of wealthy homosexuals discriminating between the pleasures of alcohol, ecstasy, cocaine and marijuana. But if their behaviour is at times mildly transgressive, no-one seems to mind, although Justin gets in a tiff when he finds his lover Robin has paid for sex with Terry, an odd job man always on the lookout for opportunities. Justin expresses his displeasure by placing some of Terry's bent black pubic hairs on the breakfast plates, then wonders if the plates are by Lucy Rie, and how much Robin paid for them.

The Spell was less than ecstatically received. Hollinghurst's next novel, The Line of Beauty (2004), returns to the 1980s of The Swimming-Pool Library, but the decade has become a site of memory. Recalling many earlier novels about AIDS, it takes its hero Nick Guest through the 1980s, and remembers the hypocrisies of a homophobic Conservative government presided over by Margaret Thatcher. Hollinghurst's turn to the past is emblematic of the rise of the historical novel as a new dominant genre in lesbian and gay fiction: his most recent novel, The Stranger's Child (2011), is a historical saga stretching from 1913 to 2008.

Many realist novels imagining queer lives in the past have appeared since Sarah Waters' first novel, Tipping the Velvet (1998), thrillingly imagined lesbian experience in the sexual underworld of Victorian London. The picaresque adventures of heroine Nan Astley, who re-invents herself first as male impersonator Nan King, a star of the Victorian music halls, and then makes money as a rentboy, sharing the streets with London's "Mary-Anns," breathed new life into a genre perceived as fusty. More recently Edmund White (Hotel de Dream, 2007), Colm Tóibín (The Master, 2004) and Emma Donoghue (The Sealed Letter, 2008) have all set novels in the nineteenth century, reflecting our abiding interest in Victorian lesbian and gay subcultures, and Jamie O'Neill's At Swim, Two Boys (2001) shows two adolescents in love in Dublin in the period leading up to the 1916 Easter Rising. Two important precursors to these historical novels are Isabel Miller's Patience and Sarah (1969), about two women living together on a farm in nineteenth-century New England, and Mark Merlis's American Studies (1994), based on the life of literary critic F. O. Mathiessen, who committed suicide in 1950.

Unlike Winterson's postmodernist The Passion and Sexing the Cherry, these novels recreate particular periods in great detail, and while they do not pretend to be objective historical documents, their verisimilitude and coherence allow the reader to imagine queer identities and desires in a time when same-sex love was still the love that dared not speak its name. Victorian fiction's shy allusions to queer criminality are supplemented by recent fiction's free representations of the "other Victorians" who populated the queer underworld of nineteenth-century London and New York. Nineteenth-century writing about queer subcultures was privately published and circulated. On the other hand, both Tipping the Velvet - complete with lesbian dildoes and aristocratic orgies - and Waters's Fingersmith (2002), a lesbian re-working of Victorian sensation fiction, became popular BBC television dramas. This popularity is not surprising. Although the queer historical novel is always implicitly political, its primary impulse is to tell exciting, emotionally complex stories, in which dramatic tension depends on the criminal status of the sexual underground, the coded and furtive nature of queer double lives. 
List of Works Cited

Allen, Carolyn. Following Djuna: Women Lovers and the Erotics of Loss. Bloomington, Indiana University Press, 1996. Print.

Andermahr, Sonya. "The Politics of Separatism and Lesbian Utopian Fiction." New Lesbian Criticism: Literary and Cultural Readings. Ed. Sally Munt. New York: Harvester Wheatsheaf, 1992. 133152. Print.

Arnold, June. Sister Gin. 1975. New York: Feminist Press at the City University of New York, 1989. Print.

Barthes, Roland. A Lover's Discourse. 1977. New York: Farrar, Straus and Giroux, 1978. Print.

Bechdel, Alison. Fun Home: A Family Tragicomic. London: Jonathan Cape, 2006. Print.

Bronski, Michael, ed. Pulp Friction: Uncovering the Golden Age of Gay Male Pulps. New York: St Martin's Griffin, 2002. Print.

Brookes, Les. Gay Male Fiction since Stonewall: Ideology, Conflict, and Aesthetics. New York: Routledge, 2009. Print.

Brown, Rita Mae. Rubyfruit Jungle. 1973. New York: Bantam, 1977. Print.

Canning, Richard. "The Literature of AIDS." The Cambridge Companion to Gay and Lesbian Writing.

Ed. Hugh Stevens. Cambridge: Cambridge University Press, 2011. 132-147. Print.

Cunningham, Michael. The Hours. 1998. London: Fourth Estate, 1999. Print.

Davidson, Guy. Queer Commodities: Contemporary US Fiction, Consumer Capitalism, and Gay and Lesbian Subcultures. New York: Palgrave Macmillan, 2012. Print.

Duffy, Maureen. The Microcosm. 1966. London: Virago, 1989. Print.

Emery, Kim. The Lesbian Index: Pragmatism and Lesbian Subjectivity in the Twentieth-Century United States. Albany: State University of New York Press, 2002. Print.

Feinberg, David. Eighty-Sixed. New York: Penguin, 1989. Print.

---. Spontaneous Combustion. New York: Penguin, 1991. Print.

Harris, Bertha. Lover. 1976. Introduced by Bertha Harris. New York: New York University Press, 1993. Print.

Holleran, Andrew. Dancer from the Dance. 1978. New York: Plume, 1986. Print.

---. Nights in Aruba. 1983. New York: Plume, 1984. Print.

Hollinghurst, Alan. The Swimming-Pool Library. London: Chatto \& Windus, 1988. Print.

---. The Spell. London: Chatto \& Windus, 1998. Print.

---. The Line of Beauty. London: Picador, 2004. Print.

Jay, Karla, and Allen Young, eds. Out of the Closets: Voices of Gay Liberation. 1972. Twentiethanniversary edition. New York and London: New York University Press, 1992. Print.

Makinen, Merja. The Novels of Jeanette Winterson. Houndmills: Palgrave Macmillan, 2005. Print.

Markowitz, Judith A. The Gay Detective Novel: Lesbian and Gay Main Characters and Themes in Mystery Fiction. Jefferson, NC: McFarland, 2004. Print.

Mars-Jones, Adam. Monopolies of Loss. London: Faber and Faber, 1992. Print.

McRuer, Robert. The Queer Renaissance: Contemporary American Literature and the Reinvention of Lesbian and Gay Identities. New York: New York University Press, 1997. Print.

Moore, Oscar. A Matter of Life and Sex. 1991. London: Penguin, 1992. Print.

Moss, Stephen. "I don't make moral judgements." The Guardian. 20 October 2004. Web. 15 November 2012. 
Murray, Simone. Mixed Media: Feminist Presses and Publishing Politics. London: Pluto, 2004. Print.

Nelson, Emmanuel S., ed. Contemporary Gay American Novelists: A Bio-Bibliographical Critical Sourcebook. Westport, CT: Greenwood Press, 1993. Print.

Pollack, Sandra, and Denise D. Knight, eds. Contemporary Lesbian Writers of the United States: A BioBibliographical Critical Sourcebook. Westport, CT: Greenwood Press, 1993. Print.

Schulman, Sarah. My American History: Lesbian and Gay Life during the Reagan/Bush Years. New York: Routledge, 1994. Print.

Smith, Patricia Juliana. Lesbian Panic: Homoeroticism in British Women's Fiction. New York: Columbia University Press, 1997. Print.

Stryker, Susan. Queer Pulp: Perverted Passions from the Golden Age of the Paperback. San Francisco: Chronicle Books, 2001. Print.

Vidal, Gore. The City and the Pillar. 1948. New York: Bantam, 1950. Print.

White, Edmund. A Boy's Own Story. 1982. London: Picador, 1983. Print.

---. The Beautiful Room is Empty. London: Picador, 1988. Print.

---. The Farewell Symphony. 1997. New York: Vintage, 1998. Print.

Winterson, Jeanette. Oranges Are Not the Only Fruit. 1985. London: Vintage, 1991. Print.

---. Written on the Body. 1992. London: Vintage, 1993. Print.

Woodhouse, Reed. Unlimited Embrace: A Canon of Gay Fiction, 1945-1995. Amherst: University of Massachusetts Press, 1998. Print.

Zimmerman, Bonnie. The Safe Sea of Women: Lesbian Fiction 1969-1989. Boston: Beacon Press, 1990. Print.

\footnotetext{
${ }^{1}$ See for example Carson McCullers, Reflections in a Golden Eye (1941); Capote, Other Voices, Other Rooms (1948); Wilson, Hemlock and After (1952); Baldwin, Giovanni's Room (1956); Isherwood, A Single Man (1964); Rule, Desert of the Heart (1964); Duffy, The Microcosm (1966).

${ }^{2}$ Stryker, Queer Pulp, and Bronski, Pulp Friction, both give useful overviews of the paperback market's representation of queer lives in postwar America.

${ }^{3}$ For an excellent reading of The Microcosm, and an account of how Duffy "incurred the almost universal opprobrium of key figures" in American lesbian literary circles of the 1970s, see Smith, Lesbian Panic 144-155.

${ }^{4}$ See "The Woman-Identified Woman," an influential 1970 radical lesbian manifesto, in Jay and Young 172177.

${ }^{5}$ See Pollack and Knight, Contemporary Lesbian Writers, for individual essays on American lesbian novelists of this period. The best monograph on lesbian fiction in the two decades after Stonewall is Zimmerman, The Safe Sea of Women.

${ }^{6}$ Simone Murray's Mixed Media gives a full account of how the women's presses promoted "writing by women from minority groups marginalised by early second-wave feminism: black women, women from ethnic minorities, working-class women, lesbians and disabled women" (73).

${ }^{7}$ See Zimmerman 143-163 and Andermahr for analyses of lesbian utopian and science fiction.

${ }^{8}$ For a full overview of lesbian and gay male detective fiction, see Markowitz.

${ }^{9}$ Although Rubyfruit Jungle was the best-selling novel of the 1970s, gay and lesbian critics have been unenthusiastic about its political and literary merits. See Emery, The Lesbian Index, 105-126 for a critical discussion of the novel's politics.

${ }^{10}$ For an account of the novel's "erotics of reading" in relation to Djuna Barnes, see Carolyn Allen, Following Djuna, 1-10.

${ }^{11}$ Schulman's essays on lesbian and gay politics, on the AIDS crisis, and excerpts from the Lesbian Avengers Handbook are collected in My American History.

${ }^{12}$ Merja Makinen's The Novels of Jeanette Winterson, with its summaries of the extensive critical writing on eight of Winterson's novels, traces debates about the relationship between lesbianism and postmodernism in Winterson's fiction.
} 
${ }^{13}$ All citations are from the 1950 Bantam paperback edition of the novel, an abridgement of the 1948 first edition. Vidal cut out much of the most interesting political material when he revised it for publication (as The City and the Pillar Revised) in 1965. Current editions follow the less interesting 1965 text.

${ }^{14}$ See Nelson for short essays, with bibliographies, on American gay novelists; for critical accounts of postStonewall fiction see McRuer, Woodhouse, Brookes and Davidson.

${ }^{15}$ See Canning for a survey of AIDS literature and critical writing about AIDS. 